The close relationship of the overcoming of this barrier to industrial development was illustrated by the building of the Keadby bridge in 1861 and its enlargement in 1916, which was followed immediately by the rapid growth of the iron-works at Scunthorpe and Frodingham.

Discussion of the major minerals was limited to the iron industry. Since this requires a complicated and very costly plant, as well as labour skilled in the handling of hot metals, it was considered unlikely that the future would bring the development of any new centres; but that, on the contrary, there would be a further concentration of the industry at Scunthorpe and Frodingham in the north and at Corby in the south. Though the prophets disagreed concerning the more distant future of these centres, they were unanimously of the opinion that their prosperity is guaranteed by their resources for many years.

In view of these facts, and of the stationary or possibly declining population of Great Britain as a whole in the coming years, it was concluded that little or no redistribution of population would follow the future exploitation of the resources of the region under discussion. It may be pointed out here, however, as a remarkable oversight, that the geographical effects of the exploitation of the coal were not discussed, for the factors which control this compel the establishment of many new centres of industry, of many new lines of transport, and a large scattering movement of population.

H. H. S.

\title{
The Scientific Delegation in India
}

\section{From a Correspondent}

Darjeeling, December 30, 1937.

$\mathrm{I}^{\mathrm{T}}$ will be remembered that the great majority of the scientific delegation to India arranged by the British Association at the request of the Indian Science Congress Association, left England on the S.S. Cathay at the end of November. Their voyage could scarcely have been more prosperous; evidently heavy weather was just escaped, and only one rather rough night, when the ship was nearing Marseilles, caused a measure of complaint; while an unexpectedly strong southerly wind in the Red Sea kept the temperature tolerable. After arrival in Bombay, the party entered upon a whirl of entertainment, sight-seeing, and travel. Every possible opportunity, however, was given and taken for conversations in matters of common scientific interest between individual visitors and residents; old acquaintances were renewed, new contacts made. Lectures and broadcasts have been given at various points, and have been received with every manifestation of interest. The reception accorded to the party has everywhere been cordial in the extreme, and the enjoyment of a wonderful journey has been complete, save for the cases of slight indisposition apparently inseparable from any visit of a party of newcomers to India, and for two major causes of general regret. One of these has been the enforced return of Dr. A. B. Rendle to England from Bombay, owing to ill-health. The other has been the serious accident to Dr. W. W. Vaughan, who in darkness at the Taj Mahal fell and sustained a compound fracture of a leg.
At Bombay, the University entertained the party. In Hyderabad State all were guests of the Government throughout the sojourn, which included entertainment, inspection of the new Osmania University, visits to the forts of Golconda and Daulatabad and the rock-hewn temples of Ellora and Ajanta, and all the transport entailed, both by rail and road. At Agra, the Taj Mahal, the fort, and Fatehpur-Sikri were seen, and it is worthy of record that both here and elsewhere such world-famous monuments have at least equalled, if not exceeded, the visitors' preconceptions of them. The Latitude Variation Observatory and the Meteorological Station at Agra, and the Moslem University at Aligarh, were viewed by those specially interested. At Delhi, on Christmas Eve and Christmas Day, the party was splendidly entertained by the Government of India and by private individuals, and a fleet of cars provided by the Government facilitated visits to points of interest. At Dehra Dun, the Forestry Research Station and the Geodetic Survey Department were thoroughly investigated, and, the weather proving kind, nearly all the party drove up to the ridge of Mussoorie, from which most of them enjoyed their first view of Himalayan snow-peaks. A few individual members diverged from the main route to visit points of special interest to them.

At Benares the whole party was entertained by the Hindu University, and attended a convocation there, a brilliant ceremony at which honorary degrees were conferred on the president-Sir James Jeans-and others. The famous river-frontage 
of the city on the Ganges was viewed from boats, and many of the party found perhaps their greatest satisfaction in wandering among the lively and infinitely picturesque streets of the Indian city.

It had been ascertained during the voyage that for a very large proportion of the party Darjeeling was the Mecca of the tour, and it was accordingly requested by wireless, and duly arranged, that the special train should proceed to Siliguri, the terminus for the mountain road and railway, after a short halt at Calcutta, where there was time for no more than a few personal introductions, and for taking temporary leave of Prof. J. N.
Mukherjee, who had accompanied and guided the party from Bombay, and to whom every member owes gratitude beyond expression.

It is from Darjeeling that this note is written. The weather, perfect throughout the tour, has favoured us to-day beyond conception: the famous views from the town and from Tiger Hill, of Kangchengjunga and its satallite range, of Makalu, of glimpses of Everest vouchsafed to some through a cloak of cloud, have reached their most splendid standard, and the half cannot be told of them. The party has to-morrow here for rest, and then returns to Calcutta for the Congress next week.

\section{Obituary Notices}

\section{Prof. H. Molisch}

$\mathrm{H}^{\mathrm{s}}$ ANS MOLISCH, whose death at the age of eighty-one years took place on December 8, was born in Brünn in 1856, the son of an intelligent and progressive nurseryman, who employed his son in his early years in his business, so that from his boyhood Molisch became interested in plants, and already when at the Grammar School in Brünn he distinguished himself by his botanical knowledge. His enthusiasm for the subject may have been further fired by his knowledge of the experimental plantbreeding which was being carried on in Brünn by the Abbé Mendel, who was a friend of his father. At any rate, when he entered the University of Vienna in 1876, he had already made up his mind to become a botanist, and in his autobiography, which was reviewed in NATURE of September 28, 1935 , p. 494, he speaks with enthusiasm of his teacher, Julius Wiesner, and also of many kindnesses he received from Kerner von Marilaun, the director of the Botanical Gardens.

Molisch's doctor's degree was awarded to him for a thesis on the anatomy of the wood of the Ebenaceæ, and he was then appointed assistant to Prof. Wiesner, a post which he retained until 1889 . Whilst acting as assistant, he became Privat dozent, and his lectures, which dealt with plant physiology, were always well attended. In 1889 he was appointed to a professorship in the Technical College at Graz, and in 1894 to the German University of Prague. While occupy. ing the former position he published his histochemistry of vegetable foods and an important physiological study entitled "Die Pflanze in ihren Beziehungen zum Eisen", in which he showed that the chlorosis induced by growing plants in a medium devoid of iron is not a direct result of the absence of that element, but is the symptom of a pathological condition induced by lack of iron, for by sensitive microchemical tests, in which he always excelled, he proved that chlorophyll itself does not contain iron. After his promotion to Prague, he devoted some attention to the lower forms of plant life, stimulated in part by a request to investigate the microflora of the water supply of Prague, which was at that time of a very impure nature. In this way he became interested in the phosphorescent bacteria and other fungi, of which he published an account, and also made important discoveries in connexion with the nutrition of Algæ. But he also continued to work on the anatomy of plants, particularly on the laticiferous tissues, and studied microscopically the phenomena associated with the freezing of vegetable tissues. In 1897 he undertook a botanical tour into the tropics, spending some time on physiological investigations in Buitenzorg and returning via China, Japan and America.

On the retirement of Prof. Wiesner in 1909, Molisch was appointed to the chair of plant physiology in the University of Vienna, which he held until 1928, when on retiring he was made emeritus professor. During this period, he received an invitation to take charge for three years of the newly established Biological Institute of the University of Tôhoku in Japan and was granted leave of absence for three years for this purpose by the University of Vienna. This Easterm visit, and a subsequent invitation to lecture and work at the Bose Institute in Calcutta, widely extended his opportunities for observation as one can readily see in his "Lebensdauer der Pflanze" (1929), in which plants from many lands are discussed.

In a more recent book, "Pflanzenchemie und Pflanzenverwandschaft" (1933), Molisch took up again what he admits was his favourite study, the microchemistry of plants, this time with a view of ascertaining what connexion exists between the chemical composition of plants and their relationship.

In all his studies, Molisch never lost sight of the applied side of botany, and his early horticultural training led him to write in 1915 a most useful "Plant Physiology as a Theory of Horticulture", which has passed through six editions and has been 